Journal of Social Sciences 8 (1): 43-49, 2012

ISSN 1549-3652

(C) 2012 Science Publications

\title{
Connecting Philosophy of Ancient Egyptians to Modern Thinking
}

\author{
${ }^{1}$ Aminuddin Hassan, \\ ${ }^{2}$ Nurul Ashikin Amir Khairul Anuar and ${ }^{3}$ Norhasni Zainal Abiddin \\ ${ }^{1,2}$ Department of Foundations of Education, \\ ${ }^{3}$ Department of Professional Development and Continuing Education, \\ Faculty of Educational Studies, Universiti Putra Malaysia \\ 43400 UPM Serdang, Malaysia
}

\begin{abstract}
Problem statement: Associating any knowledge from ancient Egyptians to modern civilization and thinking was important and had its own value. The process of understanding knowledge related to ancient Egyptians is actually based on the nature of philosophical thought. Approach: In the discussion of ancient Egypt philosophy, it is important to look at it from the perspectives of the four branches of philosophy; metaphysics, epistemology, axiology and logic. Metaphysics has two elements, which are ontology and cosmology. Arguments in ontology explain why most activities of people from the ancient Egypt involved agriculture and how they perceived their lives in the midst of this activity, this includes the concept of human creator; treatment to man and woman; and Egyptians' Gods and Goddesses. In addition, cosmology analyses the universe; everything inside and out of it, as well as what makes them stay and move. Results: Whereas, epistemology refers to how ancient Egyptians appreciated the existence of knowledge among them by considering the sources, types, categories and importance of particular knowledge that was gained in different ways. Besides, the aspects of axiology are also discussed here, especially in the ancient Egypt's hieroglyphics. This writing discusses the level of aesthetical value posed by all these Egyptians, even at the time of about 3000 B.C. They could discuss to form pictographic as their written language. This activity lasted for thousands of years. Conclusion: Last but not the least, logic is another aspect that can be used in the discussion across metaphysics, epistemology and also axiology, for instance, the thinking of the philosophy behind Egyptians life. This writing relates the philosophy of ancient Egypt with the life of the modern world, not only in Egypt, but also in another part of the world, which exist from the impact of the philosophy of ancient Egypt. Modern views of Egyptians' thinking are often vastly based on what their people had and thought of in the ancient days.
\end{abstract}

Key words: Ancient Egyptians, natural phenomena, marriage system, ontology explain, greatest world powers, analyze the philosophy behind, metaphysical aspect

\section{INTRODUCTION}

The magnificence of the kingdom of Egypt is wellknown over the centuries. Emerged along with the other Western and Asian civilizations, it is the most anciently known civilization in Africa. Egypt, profited from the location in the northeastern corner of Africa and strategic hub for trade routes between Africa, Europe and Asia, had grown rapidly in the economical aspect and development of the city. Ancient Egyptians transformed the country into an empire and also one of the greatest world powers. Besides that, ancient Egyptians were also well-known for its precious art, in terms of literature, architecture and sculpture (Murray, 2004). The ancient Egyptians had developed much technical knowledge, including craft, mathematics and medical science during their era. There are some arguments that claim the earliest knowledge and philosophy is started from Egypt, before it was developed into various aspects of knowledge and philosophy of the ancient Greek, followed by other ancient conventional eastern philosophies. In fact, every aspect of Egyptians' knowledge seems to be completed at the very beginning and virtually has no signs of development (West, 1993). Are the Egyptians' ways of life, philosophy, religion, language and art related to

Corresponding Author: Aminuddin Hassan, Department of Foundations of Education, Faculty of Educational Studies, University Putra Malaysia 43400 UPM Serdang, Malaysia 
the modern thinking? Or are they relevant to the modern world and thus, persist without change? Hence, it is important to study and amplify this issue to analyze the philosophy behind the existence of the great Egypt civilization.

\section{Review of literature:}

Metaphysical aspect of ancient Egyptians: The metaphysical aspect is important as a basis to understand the way people look at any particular situation or belief higher than the physical realm. In Egyptology, the perspective of metaphysical aspect can be reviewed by looking at their daily life, practical activities and condition of the society. The question about nature and universe is one of the scopes discussed under the branch of metaphysics.

Egypt is unlike other countries from any parts of the world. The most distinctive characteristic of the land is its longest river, called Nile Valley. As been spoken by Herodotus; the ancient Greek historian, "Egypt is the gift of the Nile". The civilization of the Egyptians was based on the Nile River, where it played an important role in the development of the Egypt's economy. With its annual flood, the Nile brought in fertile silt that made the food production and agricultural activities become possible (Casson, 2001). The Nile River was also used for transportation and communication (Ruiz, 2001). If the river appeared to have granted the Egyptians in living, the desert barriers that bordered the valley of the Nile had given them security and discouraged invasion from other civilizations (Bierbrier, 2008). Despite all the privileges that the land of Egypt provided, the ancient Egyptians had created their own belief. They believed that the inundation was the gift of the gods (Littleton, 2005). But, if things were not going smoothly such as the annual inundation of the Nile was too high or too low, it was because the river was angry, instead of assuming that as the natural phenomena (Casson, 2001). In addition, the Egyptians also believed that the pharaoh and the priest have the supernatural power. When the things were going well, the people believed that their pharaoh and the priest were doing their jobs well. However, if things went wrong, they would blame them (Littleton, 2005). This situation is slightly different as compared to the modern thinking. The exposure to the knowledge of meteorology and geography allows modern people to live at the mercy of natural forces that are completely beyond the Egyptians' control. Furthermore, they had faith in God and accepted natural disasters as a test from God.

Another element of metaphysical aspect that can be discussed is religion. The religion of ancient Egyptians was based on polytheism; which refers to the worshipping of more than one god (Littleton, 2005). It is said that the Egyptians had over 700 gods and goddess along with various beliefs. Each one of them has their own power and role, in order to protect the land of Egypt and ensure their people to live in harmony. The spiritual world that was created by the ancient Egyptians is full of mysteries and myths. The gods and goddess of their beliefs were portrayed in many ways, which includes the forms of animal, natural force and human, or the combination of human and animal (Casson, 2001). For example, Khnum, the God of Inundation, had the head of a curly-horned ram and a body of a human. Even though the Egyptians characterized their gods as animal-headed images, they did not believe that the gods was actually animals but they merely aimed to symbolize the power of their deities through animals.. There were two chief gods that ruled their kingdom. First is the king of the gods called Amon-Re, who was believed to be the God of the Sun and the Lord of the Universe, whereas Osiris was the God of Underworld (LaFontaine, 2002). The ancient Egyptians believed that it was important to recognize and worship these gods and goddesses, so that their life would go smoothly (Fagan and Garrett, 2001). Polytheism still persists in the modern world today. Most of the world religions have the splendors of polytheism, but in different orientations, such as Hinduism, Buddhism, Confucianism and Taoism. There are also religions that have faith in only one god, which are called monotheistic religions, for example, Islam, Christianity and Judaism (Littleton, 2005). These religions are widely practiced throughout the world.

Things that related to the religion are beliefs and to Egyptians, the religion influenced their whole life and culture (Kaplan, 2004). The history of the great pyramid, temples, tombs and mummies are the proofs of the religious forces that shaped the ancient civilization of the Egypt. Religion is also responsible to the Ancient Egyptians' belief concerning life after death (LaFontaine, 2002). Initially, only pharaohs were entitled to an afterlife, but gradually, the nobles also got the royal permission to do so (Casson, 2001). In the emergence of the New Kingdom, the practices had widened to include all the Egyptians. For those who could afford to pay the priests, they could request the priests to intone them at burial or get an artisan to inscribe them on coffin walls or papyrus rolls. On the contrary, the poor Egyptians could expect little on their burial but it was just enough for the preparation needed for afterlife (Hamilton, 2007). The shallow grave near the desert was common burial spot for them who couldn't afford the expenses. The philosophy of 
afterlife to the Egyptians is the corporeal existence, which strongly believed the soul left the body after the death, but was expected to return back throughout eternity (Challen, 2005). That is the reason why they had to preserve their bodies from decomposition and it was done through the detailed process of mummification (Ruiz, 2001). Although the Egyptians viewed the afterlife as a cycle of rebirth, the existence of eternity was only available for those who were qualified after the judgment of Osiris, i.e., the Egyptians' God of the Underworld (Casson, 2001). The belief about life after death has connection with the modern people's belief as well, based on their respective religions. Despite the ritual of preserving the dead body through mummification process, the Islam doctrine claims that human existence continues after death in the form of spiritual and physical resurrection. Similar to the Egyptians, Muslims also believe in 'Judgment Day', where rewards and punishment will be given for one's actions during life.

In the ancient world, women in Egypt had better social treatment as compared to other ancient cultures. Although their position was generally secondary to that of men, they play subordinate role to men in Egyptian society. The primary role of a woman in ancient Egypt was to be a wife who managed the household. They are called mistress of the home (Bierbrier, 2008). Those who could produce more children for the hereditary often had a higher status in the society. Even though the rule stated that women were excluded from administrative and governmental, but in the Egyptians' history there were powerful queens that ruled Egypt (Rice, 1999). The most famous queen of Egypt was Cleopatra IV. The women of the Egypt had the right to own properties, inherit the properties to their daughters and also to manage their properties. Women can also appear in court without any male guardian (Bierbrier, 2008). Although Egyptian women rarely held the post as priest (a high-ranking position in the society), they played important roles in temple rituals, as singers and musicians (Hawass, 2009). As for the modern people, they believe gender fairness in the society, economy and politic. Undeniably, the women nowadays contribute as much as men in the development of a country. Women also gained more opportunity in education compared to the ancient world, which provided schooling to men only, whilst women learned household chores from their mothers. The number of women with better prospect in occupation and their participation in professional jobs are also increasing.

Epistemology aspect of ancient Egyptians: Epistemology is normally discussed by looking at the source, type, category and structure of knowledge. In this writing, the epistemological aspect of the ancient Egyptians' philosophy can be reviewed through their education system and the development of knowledge. Theory of knowledge on ancient Egypt dynasty has started before 1000 B.C and became more tangible during Middle Kingdom (Smith, 2004; 2005). The process of obtaining knowledge began at home indirectly. The children at their early age learned basic education from their parents. Boys are more likely to be educated by their fathers or close relatives. Usually, they followed their fathers' footsteps and practices (Bierbrier, 2008). Meanwhile, girls were trained at home by their mothers on how to take care of the household and children (Strouhal, 1992). In the school, children received proper training about writing, reading, mathematics and also moral subject. However, not everyone had the opportunity to get an education and have the chance to attend schools, unless they came from families of higher status and income (Bierbrier, 2008). The education system today is very much contradicted to the ancient Egyptian. Modern education is made compulsory for both genders to attend schools. Today's education methodology does not stress on memorizing facts, but focuses more on student centered learning and creative thinking. Student who are slow in learning do not receive harsh punishment like the students in the past, but they are given more attention and guidance by the teachers.

It is stated that Egyptians mythology, symbolism, hieroglyphics, medicine and astronomy were fully developed in the early dynasties (West, 1993). The early Egyptians wrote on papyrus; a particular kind of study which is also used for calculation. Apart from using papyrus as a mathematics exercises for children, it was also used by the Egyptians' administration to compute the taxes, survey land, measure weight, as well as distance and reckon time (Strouhal, 1992). Medical science have also been claimed to begin from Egypt. The earliest recorded system of medical treatment was found written on papyrus over the past 100 years. The medical texts that had been documented by the ancient Egyptians, include the body structure, diseases, medical instruments, remedies, eye diseases and women diseases (White, 2003). To Egyptians, their medical practices were inseparable from spiritual rituals. They would use healing spell and asked the gods for help if there were any health problems before giving medical cure. Although their knowledge in ancient time was surrounded by superstition, the medical practice was fairly advanced in ancient Egypt and the Egyptian doctors and surgeons achieved well-known reputation 
(Casson, 2001). In the modern invention of medical science, there's a clear border between superstition and medicine, unlike the ancient healers. However, the ancient Egyptian medical texts on surgical trauma, entitled 'The Edwin Smith Papyrus' is the medical papyri that persists until today (West, 1993). This is because the content of the text presents a rational and scientific approach to medicine in ancient Egypt. In addition, prayers and blessing to god somehow could be considered as spiritual forces and it has been practiced widely among the religious people of the modern society.

The existence of pyramid is the evidence of the knowledge development during the ancient Egypt . It is a common perception that the Egyptians did have some power machineries to build the pyramid. There were also some rumours that claimed the pyramid to be built by magic power or aliens from outer space. There was also a story reported that 100,000 slaves had worked on the Great Pyramid. However, there were about 4,000 construction workers involved at that time only, including free citizens and professional workers (White, 2003). There was no powerful machinery. Instead, the Egyptian engineers used very simple method with the knowledge of geometry, astronomy and architecture that they had. From the ancient Egypt until modern times, it seems that much of the techniques and knowledge from the ancient Egypt continue to be developed with little or basic scientific knowledge (West, 1993).

The ancient Egyptians have a formal writing system called 'hieroglyphs' (Wilson, 2003). A hieroglyph is a form of picture-writing to represent different object, action, sound and ideas. In their world, hieroglyphs writing were used widely in daily life. For example, in scribe school, in the field, army, government and temple. The ancient Egyptians wrote on papers and carved in stones. Hieroglyphs writing were also found on the walls of tombs and pyramids. The ancient Egypt has fascinated the world with their unique art of picture-writing for more than hundred years. However, Egyptologists were unable to comprehend the meaning of the inscription surviving on the monuments. The mystery remains until 'Rosette Stone' finally discovered the secret (Casson, 2001). The reveal of hieroglyphs have led to the discovery of the lost world of Egypt to the modern world. It was the beginning of modern study of Egyptology. The expenditure of hieroglyphs was among the first in the history of literature. The writing system from the ancient world then slowly changed through some developmental stages, which is from picture-writing to the letter-writing system. The nature of writing has been constantly transformed, due to the development of new innovation and technology.

It is therefore useful to look at the source, category and type of knowledge in order to understand the history of the ancient world and its people. It is also important to see the impact of knowledge towards a civilization, followed by the comparison between the philosophy of ancient Egyptians and the modern thinking.

Axiology aspect of ancient Egyptians: Axiology is a branch of philosophy that focuses about the theory of value, which can be categorized into two kinds of values, i.e., ethics and aesthetics. In this writing, the axiological aspect of philosophy of ancient Egyptians can be connected to modern thinking by looking at their social system. The social hierarchy in civilization refers to a system which groups the society based on their status. Ancient Egyptians were generally divided into 3 social classes; upper class, middle class and lower class. At the highest ranking of Egyptian society was the pharaoh, who was believed as the God on Earth and King of the State. The pharaoh owned all of the land of Egypt and directed the energy of people. They are the ones who decided what was right or wrong and set the law. Below him stood the nobles and priest in the same class. The nobles and priest received high status because the religion was an important element in the ancient Egyptians' life. The priest's role was to care for the needs of the gods and also responsible for religious rituals. Meanwhile, the nobles helped the pharaoh to administer the country and lead the society. Middle class consisted of scribe, merchants, artisans and skill laborers such as craftsmen. Scribes were the highest servants of the government, which were responsible for the art of writing and acted as the keepers of all government's records. Their jobs were highly regarded in an ancient Egypt due to the fact that only a few of Egyptians could read and write. The craftsmen worked at the state or temple estates. They are responsible for carving statues and ornaments. Lower class represented the largest number of the society. The slaves and outcasts were placed at the lower class, since they were either prisoners of war or convicts. Slavery in ancient Egypt was not as bad as the modern perception. There was no large-scale of exploitation to slavery. In fact, most slaves were used in a domestic context as local servant. Some of them were trained in personal service such as to work as maids, played musical instruments and as caretakers of noble Egyptians' households (Bierbrier, 2008).

Whether in the ancient or modern world, the division of social classes still persists and this scenario keeps the discussion on social values going. However, 
in today's society, we are generally grouped into 4 social classes; the upper class, the middle class, the working class and the lower class (Perry et al., 2008). This method of classification is based on the status of profession rather than on the traditional ranking. The upper class consists of individuals with have considerable power over the economic and political at their nation. They are the rich and wealthy people who are able to enjoy a much higher living standard than the rest of the community. The middle class consists of white-collar professionals like lawyers, doctors and teachers who enjoy a reasonable standard of living. The working class is mainly made up of blue-collar workers and manual laborers, who cannot survive without a salary and own few properties. Whereas, the lower class is mainly consists of the poor, homeless and permanently unemployed, who are dependent on the country to provide them with the basic needs of life. They are usually the ones who suffer from discrimination since they are regarded as useless and a burden to the society. Is the modern social division better than the ancient one? The difference among these two systems of social status is, in ancient Egypt, people were forced to be in a particular social class from their birth to their grave. This is because wealth, power, rank and even careers were inherited. For example, sons of farmers or craftsmen would join their dads in their professions, whereas the nobles were close relatives of pharaoh and held an important role in the country. In the modern society, people can improve their own destiny and status depending on the knowledge and ability that they have.

The axiological approach can also be discussed in the term of marriage system. To an Egyptian, marriage was an important element in their society and it played a major role which every men and women must fulfill in order to build a family. This is indeed a very significant value in an established society. The royal family of ancient Egypt could have a marriage between a brother and a sister or between a father and a daughter. The main reasons behind this brother-sister's marriage are to secure the power and properties within their families, although it was not obligatory to practice this within the royal family (Meskell, 2002). The marriage between people who's biologically related, however, is not acceptable in the modern life and against some religious beliefs. The value of marriage is therefore clearly defined to avoid any problem in future. Ancient Egyptians were believed not having arranged marriage, as they could choose their mates. Many love poems were discovered, leading to the fact that the ancient love was very similar to the modern idea of love. However, the patterns of marriage were shift based on the decreasing numbers of registration marriage in the modern life. This occurred due to the factor that the society today is more concerned into the development of their career rather than to start a family. In addition, the modernization of the culture today allowed people of many countries to live together without any legally bound marriages.

Sometimes, a marriage doesn't end with eternal happiness as expected by couples. There were many reasons for divorce to occur back then, just like today. The time will come when separation is the best solution for the problem. Generally, ancient Egyptians might have a slightly easier procedure to end a relationship. A man only need to declare his intention to divorce in front of his wife and witnesses, without involving any documentation or being tied by law and religious authorities (Bierbrier, 2008). Once an Egyptian's marriage is over, the ex-wife would be given prior custody of their children (Hawass, 2009), same as the situation in modern life today. They were also free to remarry again. A divorced wife or widower could also keep their own property or was subjected to one-third of the assets which were gained during the period of marriage (Bierbrier, 2008).

The aesthetical value in the axiological aspect of ancient Egypt can be studied through its literature and arts. The greatest element in this civilization was its arts. In ancient Egypt, art was originally created for religious and superstitious purpose, rather than decorative purpose (Casson, 2001). Royal tombs, temple of gods and statue represent the world of art of the Egyptians. Tombs and temple were executed in stone with relief decoration on their walls (Kaplan, 2004). The decoration in tombs was created to depict the activities that the deceased wanted to do and enjoy in their afterlife. The tombs were important to ancient Egyptians because they believed that the dead person's spirit could survive forever inside the tombs. The royal reliefs on the temple of the god's walls were functionally done to show the majestic power of the kings and also beneficence of the gods. The inscription on the walls of temples, tombs and monument had revealed the Egyptian's belief about their world, in the context of social and religion (Shaw, 2003). It had preserved many of the historical records, biographies, incantation and prayers that the Egyptians recorded with their writing.

Ancient Egyptians' literature was initially influenced by religious belief, but it quickly evolved and grew in a wide diversity of type and subject matter. During the Old Kingdom, the religious literature of ancient Egypt included the stories of the gods' deeds, mythological and magical text. During the Middle Kingdom, the tone of the literature had change into more various genres, such as novels, short stories, 
poetry, tales, proverb, moral teaching, philosophical meditation and literary messages. 'Wisdom literature' was a favorite in Egyptians' letters and the most popular of all period (Bierbrier, 2008).

This section has discussed the relevant theory to appreciation of values in ancient Egyptians' era, which are all the important elements of axiology.

Logical aspect of ancient Egyptians: The logical aspect of philosophy of ancient Egyptians can be connected to modern thinking by looking at their daily life and culture. One of the interesting aspects that can be discussed here is the concept of marriage in ancient Egyptians. It involved reasoning and the use of deductive and inductive thinking, which indirectly produced a complete set of measurements and judgments. The romantic concept of marriage is universal, which is based on the love between two people who are willing to share their life together. Nevertheless, it could also involve more than two partners in a marriage, which is called 'polygamy'. It is not a rare thing that occurred to the ancient Egyptians. According to their records, the Egyptians pharaoh, Amenhotep III had been said to have taken over 300 wives during his lifespan (Manniche, 1997). The idea of polygamy for the king was actually related to political reasons. Pharaoh practiced polygamy which helped them to assure a royal heir, in order to strengthen the relationship with foreign countries or even powerful regional leaders, as well as to establish their dynasties. Although polygamy was widely practiced by royal class and some of the highest officials, the situation was exactly opposite for the common Egyptians. Most marital relationship among them was monogamous (Bierbrier, 2008). The logical reason behind this is in term of economic reason, as the man could not afford to support more than one wife at the same time. But in the modern life, having more than one wife is not likely to be a burden to a husband. Insteadm, it was an economic asset for the institutional marriage. This is because most women nowadays contributes to the economic development and can stand on their own feet. They have their own career and sometimes their earnings are higher than the husband himself. Even some of the religions allow the practices of polygamy. Back to the ancient Egyptians, most men preferred to have simply affair with prostitutes, concubines or slave girls rather than to take a second wife, in order to avoid from being responsible for the maintenance of several women (Bierbrier, 2008).

It is not complete to discuss about ancient Egypt without talking about the pyramid; things that sets Egypt apart from the other ancient world. Because of its uniqueness and extraordinary size, the great pyramid is listed as one of the seven wonders in the world. The great pyramid, known as 'Akhet Khufu'. Having a height over 451 feet at the base and containing about 2.5 million stone blocks with the weight of 2.5 tons, it is the largest constructed mass of stone ever built by men (Fagan and Garrett, 2003). Logically, why did the pharaoh invested most of their country's manpower, material and wealth to construct such an enormous structure during their era? For what purpose exactly was the pyramids erected? There are various arguments and views that are evoked by the Egyptologist. Most Egyptians believed that the pyramids were meant to serve as a tomb for the pharaohs. Another opinion stated that the only motive for constructing them was because the king was determined to keep their treasure from being stolen. This is because the dead pharaohs were found to be buried along with their goods and properties. Assumptions are also made that this is due to the pharaohs' obsession of the belief towards afterlife (Littleton, 2005). They believed that the building that contains the tombs and mortuary temples could help to ensure their immortality. It is claimed to be the resting place for the souls of the deceased before the journey to the world of afterlife began (Hamilton, 2007). Nonetheless, most Egyptologists agreed that it had to do with Egyptians' worship of the God of the Sun , Amon-Re. According to a myth, the pharaohs believed that they will join the Amon-Re on their journey across the heaven after their death (Fagan and Garrett, 2003). Regardless of ny reasons, the pyramids still persist until today as a symbol not only to represent the mightiness of the pharaohs, but also as an impressive accomplishment which symbolizes the skillfulness in craftsmanship and arts of the ancient Egyptians. In the modern world, the construction of buildings with variety of great, unimaginable designs or ideas are done, in order to express their status as prosperous, developed country. Perhaps it was also to show their development in architecture and technology-based field, instead of being influenced by religious or myth factors as seen back in the ancient history.

Among the different perspectives, logic is the aspect that related in the discussions across all other philosophy branches; metaphysics, epistemology and also axiology. For instance, in this study it was connected to the philosophy of Egyptians' life. Logical approach is used for the argument and reasoning about ancient Egypt to be in accordance with an approved way and systematic approach of thinking. . In addition, it is useful to apply logical thinking to evaluate the past and the present in many aspects of life that ancient Egyptians had led, in order to understand the everyday life of ancient Egyptians. 


\section{CONCLUSION}

Research in Egyptology had been carried out widely by many who were fascinated by the history of ancient Egypt. The civilization of ancient Egyptians which lasted over 3,000 years has generated public interest to explore its mysterious and mystical world that lies beyond its great reputation. In conjunction to the needs to discover human history, this writing is important to relate modern people's thinking with ancient Egyptians. In future, some research in relation to this topic should be conducted to evolve more knowledge about Egyptology. In conclusion, it is a fact that the modern thinking is connected to the philosophy of ancient Egyptians in various aspects, such as the way of life, culture, society, art, literature and knowledge. This is because ancient Egyptians' civilization has contributed in some way of the modern life, especially for the modern Egypt itself.

\section{REFERENCES}

Bierbrier, M.L., 2008. Historical Dictionary of Ancient Egypt. 2nd Edn., Scarecrow Press, Lanham, ISBN10; 0810857944, pp: 429.

Casson, L., 2001. Everyday Life in Ancient Egypt. 2nd Edn., JHU Press, Baltimore, ISBN-10: 0801866014, pp: 163.

Challen, P., 2005. Life in Ancient 1st Edn., Egypt. Crabtree Publishing Company, USA., ISBN-10: 0778720381, pp: 32.

Fagan, B.M. and K. Garrett, 2001. Egypt of the Pharaohs. 1st Edn., National Geographic Society, Washington, D.C., pp: 288.

LaFontaine, B., 2002. Gods of Ancient Egypt. 1st Edn., Courier Dover Publications, Mineola, N.Y., ISBN10: 0486420884, pp: 32.

Hamilton, R., 2007. Ancient Egypt: The Kingdom of the Pharaohs. 1st Edn., Parragon Inc., Bath, U.K., ISBN-10: 1405486430, pp: 96.

Hawass, Z., 2009. Silent Images: Women in Pharanoic Egypt. 1st Edn., American University in Cairo Press, Cairo, ISBN-10: 9774162021, pp: 208.

Kaplan, L.C., 2004. Art and Religion in Ancient Egypt. 1st Edn., Rosen Classroom, New York, ISBN-10: 0823989321, pp: 24.
Littleton, C.S., 2005. Gods, Goddesses and Mythology. 1st Edn., Marshall Cavendish, New York, ISBN10: 0761475591.

Manniche, L., 1997. Sexual Life in Ancient Egypt. 1st Edn., Keegan Paul International, London, ISBN10: 0710305516, pp: 127.

Meskell, L., 2002. Private Life in New Kingdom Egypt. 1st Edn., Princeton University Press, New Jersey, ISBN-10: 069100448X, pp: 238.

Murray, M.A., 2004. The Splendor That Was Egypt. 1st Edn., Courier Dover Publications, Mineola, N.Y., ISBN-10: 0486431002, pp: 384.

Perry, M., M. Chase, M. Jacob and J.R. Jacob, 2008. Western Civilization: Ideas, Politics and SocietyFrom 1600. 1st Edn., Cengage Learning, Boston, ISBN-10: 0547147465, pp: 902.

Rice, M., 1999. Who's who in Ancient Egypt. 1st Edn., Routledge, New York, ISBN-10: 0415154480, pp: 257.

Ruiz, A., 2001. The Spirit of Ancient Egypt. 1st Edn., Algora Publishing, New Yor, ISBN-10: 1892941686, pp: 281.

Shaw, I., 2003. The Oxford History of Ancient Egypt. 1st Edn., Oxford University Press, New York, ISBN-10: 0192804588, pp: 525.

Smith, G.E., 2004. The Ancient Egyptians and Their Influence upon the Civilization of Europe 1911. 1st Edn., Kessinger Publishing, USA., ISBN-10; 1417977337, pp: 240.

Smith, B.G., 2005. Women's History in Global Perspective. 1st Edn., University of Illinois Press, Chicago, ISBN-10: 0252029976, pp: 312.

Strouhal, E., 1992. Life of the Ancient Egyptians. 1st Edn., University of Oklahoma Press, Norman, ISBN-10: 080612475X, pp: 279.

West, J.A., 1993. Serpent in the Sky: The High Wisdom of Ancient Egypt. 1st Edn., Quest Books, Wheaton, ISBN-10: 0835606910, pp: 266.

White, B.L., 2003. Ancient Egypt Provides an Early Example of How a Society's Worldview Drives Engineering and the Development of Science. The Strategic Technology Institute.

Wilson, P., 2003. Sacred Signs: Hieroglyphs in Ancient Egypt. 1st Edn., Oxford University Press, United Kingdom, ISBN-10: 0192802992, pp: 157. 